\title{
Pemrograman Mikrokontroler Guna Memperkenalkan Industri 4.0 di SMA Negeri 7 Tangerang Selatan
}

\author{
Meyhart Bangkit Sitorus ${ }^{1}$; Tri Joko Purnomo² ${ }^{2}$ Juara Mangapul Tambunan ${ }^{3}$; Hastuti Aziz. ${ }^{4}$; \\ Pawenary ${ }^{5}$
}

\author{
1, 2, 3, 4, 5 Departemen Teknik Elektro, Sekolah Tinggi Teknik PLN \\ bangkit@sttpln.ac.id
}

\begin{abstract}
ABSTRAK
Dewasa ini, teknologi berkembang sangat cepat dan ilmu pengetahuan di bidang Teknologi Informasi dan Komunikasi (TIK) terus menjadi perbincangan utama. Dengan masuknya era internet maka terciptalah Industri 4.0 yang saat ini terus dikembangkan oleh para ilmuwan guna memudahkan kehidupan manusia. Terdapat beberapa bidang ilmu pengetahuan dasar yang dibutuhkan untuk mengembangkan Industri 4.0, salah satunya yaitu pemrograman.Permasalahan yang dialami oleh anak SMA setelah lulus dan kemudian masuk di perguruan tinggi di bidang teknik, terkhususnya jurusan Teknik Elektro adalah mereka belum mengenal pemrograman. Hal ini disebabkan karena dihapuskannya mata pelajaran TIK pada jenjang SMA sejak diterapkannya kurikulum 2013. Karena lulusan SMA tidak memiliki bekal di bidang teknik, maka sedikit pula dari mereka yang ingin melanjutkan pendidikan di bidang teknik. Kegiatan PKM ini merupakan pelatihan pemrograman yang menjadi dasar pengetahuan untuk mengembangkan Industri 4.0. Pelatihan dikususkan pada pemrograman mikrokontoler dengan menggunakan Arduino Uno sebagai media pembelajarannya. Pada akhir kegiatan siswa diberikan kuesioner yang diukur dengan lima skala Likert untuk mengevaluasi seberapa efektif pelatihan yang dilakukan.Pelatihan diikuti oleh tiga puluh sembilan murid SMA Negri 7 Tagerang Selatan yang berada pada jenjang kelas XI jurusan IPA dan tertarik dengan pelajaran mengenai komputer. Setelah kegiatan pelatihan, hasil kuesioner menyimpulkan bahwa peserta "Setuju" sebanyak 61.53\% dan "Sangat Setuju" sebanyak 33,33\% bahwa pelatihan ini menambah wawasan mereka mengenai Industri 4.0. Peserta "Sangat Setuju" sebanyak 43,58\% dan "Setuju" sebanyak 33,33\% bahwa dirinya tertarik untuk mendalami Mikrokontroler Arduino. Peserta "Sangat Setuju" sebanyak 43,58\% dan "Setuju” sebanyak 41,02\% bahwa ingin ada pelajaran tambahan mengenai mikrokontroler di sekolah mereka.
\end{abstract}

Kata kunci: Pemrograman, mikrokontroler, Indusrtri 4.0

\begin{abstract}
Today, technology is growing very fast and science in Information and Communication Technology (ICT) is still the main topic. The entry of the internet era created Industry 4.0 which is currently being developed by scientists to facilitate human life. Required several fields of science needed to develop Industry 4.0, one of which is programming. The problems obtained by high school students after graduating and then entering college in engineering, especially those majoring in Electrical Engineering are they have just come to know programming. This is due to the elimination of ICT subjects at the high school level since the implementation of the 2013 curriculum. Because high school graduates have no provision in engineering, few also want to improve their education in engineering. This PKM activity is a programming training that becomes the knowledge base for developing Industry 4.0. The training was focused on microcontoler programming using Arduino Uno as a learning medium. At the end of the activity, students were given a questionnaire containing five Likert scales to evaluate how effective the training was conducted. The training was attended by thirty nine students of South Tagerang 7 State High School who were in accordance with the grade $X I$ majoring in science and interested in computer assistance. After the training, the results of the
\end{abstract}


questionnaire concluded that participants "Agree" 61.53\% and "Strongly Agree" 33.33\% that this training increased their insight into Industry 4.0. The "Strongly Agree" Participant was $43.58 \%$ and "Agree" 33.33\% that he was interested in exploring the Arduino Microcontroller. Participants "Strongly Agree" 43.58\% and "Agree" 41.02\% that they want additional lessons on the microcontroller at their school.

Keywords: Programming, microcontroller, Industry 4.0 


\section{PENDAHULUAN}

Ilmu pengetahuan di bidang teknologi dan informasi terus berkembang pesat belakangan ini. Dalam perkembangannya, terdapat suatu pengetahuan yang sangat mendasari berkembangan kedua hal tersebut, yaitu pemrograman atau coding. Tetapi, di Indonesia sangat sedikit sekolah yang memasukkan pelajaran atau ekstra kurikuler pemrograman dalam kurikulum sekolah, baik di tingkat SMP maupun SMA. Hal ini bisa dikarenakan belum diarahkan atau diberikan kebijakan dari kementrian pendidikan untuk diberikan pelajaran pemrograman. Bisa juga dikarenakan kemampuan pengajar yang belum kompeten di bidang pemrograman.

Seorang anak bernama Yuma Soerianto ( 10 tahun ) sebagaimana dilansir dalam Kompas.com[1] belajar pemrograman menggunakan media pembelajaran Youtube. Dirinya mampu membuat lima buah aplikasi yang membuat dirinya diundang dalam acara Worldwide Developers Conference (WWDC) di San Jose (AS) pada 2017 dan bisa bertemu langsung dengan CEO Apple Tim Cook. Hal ini menunjukkan bahwa umur bukanlah suatu alasan untuk siswa SD, SMP maupun SMA tidak mampu untuk belajar pemrograman.

Pengetahuan pemrograman adalah sangat penting untuk mendukung perkembangan Industri 4.0. Dengan memperkenalkan pengetahuan pemrograman kepada masyarakat, mereka menjadi paham logika-logika sederhana dalam pemrograman, khususnya dalam pelatihan ini yaitu siswasiswi di SMA Negeri 7 Tangerang Selatan. Pelatihan yang diadakan oleh tim PKM dipersiapkan oleh para tim dosen dan mahasiswa, kemudian dibawakan dalam bentuk workshop sehingga para siswa bersentuhan langsung dengan alat mikrokontroler dan memprogramnya menggunakan komputer.

Para tim dosen melakukan kegiatan pengabdian pada masyarakat ini bukan hanya mengajarkan saja, tetapi juga lebih mendalami pemrograman mikrokontroler dan juga Industri 4.0 untuk pengembangan diri. Sebagaimana telah dijelaskan oleh seorang dosen Teknik Elektro Hoedi Prasetyo, bahwa tren perkembangan riset mengenai Industri 4.0 meningkat sebanyak dua kali lipatnya setiap tahun mulai dari tahun 2013 sampai 2016 [2]. Dari hasil studi literaturnya Hoedi Prasetyo mendapatkan bahwa pada bidang manufaktur adalah jumlah riset yang paling banyak ditemui, yaitu sebanyak 58\%. Tren peningkatan jumlah publikasi ini menandakan bahwa dari sisi akademik Industri 4.0 mendapat perhatian lebih di tahun-tahun belakangan ini, sehingga dosen STTPLN juga tidak boleh ketinggalan untuk mendalami bidang pengetahuan ini.

Kegiatan yang dilaksanakan ini adalah kegiatan pelatihan yang dipelopori oleh Dosen-Dosen Elektro dan mahasiswa STT-PLN guna memperkenalkan, melatih dan mengajarkan siswa-siswi terkhususnya SMA mengenai pemrograman, secara khusus pemrograman mikrokontroler. Kegiatan ini sekaligus memperkenalkan era industri 4.0 dimana pemrograman memegang peranan penting dalam industri.

Belakangan ini banyak sekali siswa-siswi setelah selesai SMA, mereka ingin masuk ke perguruan tinggi dengan jurusan Managemen, Ekonomi dan Hukum. Sedangkan bidang Teknik berada pada pilihan belakang. Termasuk jurusan Teknik Elektro menjadi pilihan jurusan yang kurang diminati. Hal ini bisa jadi disebabkan kurangnya mata pelajaran yang menyinggung dengan bidang Teknik sewaktu siswa-siswi tersebut menjejaki pendidikan sebelum kuliah. Padahal di era milenial ini akan sangat banyak dibutuhkan ahli di bidang teknik untuk menumbuhkan perekonomian bangsa Indonesia.

Pelatihan ini diberikan juga untuk menumbuhkan rasa keingintahuan dan ketertarikan para siswa-siswi untuk menjejaki bidang Teknik, secara khusus Teknik Elektro ketika mereka memasuki jenjang kuliah nanti. Sebab itu dalam pelathan akan dibuat menarik bagi siswa-siswi untuk belajar 
pemrograman. Menunjukkan bahwa memprogram mikrokontroler adalah tidak sulit dan menyenangkan.

Feedback dari siswa-siswi juga adalah penting untuk diketahui. Oleh sebab itu perlu diberikan quesioner kepada para siswa-siswi setelah melakukan pelatihan mikrokontroler. Quesioner yang diberikan berupa pertanyaan yang bisa dijawab oleh siswa-siswi secara khusus mengenai pemrograman dan pelajaran yang mereka dapatkan di hari tersebut.

\section{METODE PELAKSANAAN}

Secara garis besar Program Kemitraan Masyarakat yang dilaksanakan ini adalah pelatihan. Sebagaimana diketahui bahwa mulai kurikulum tahun 2013, pelajaran Teknologi Informasi dan Komunikasi (TIK) sudah dihapuskan, sehingga siswa SMA sudah tidak lagi mendapat pelajaran mengenai komputer. Kegiatan PKM ini adalah untuk memperkenalkan pemrograman khususnya mikrokontroler kepada siswa-siswi SMA, sehingga para penerus bangsa ini tidak ketinggalan dari perkembangan dunia yang sedang mengarah pada kecanggihan teknologi khususnya di bidang TIK.

Metode pelaksanaan yang secara ringkas dapat dilihat pada diagram alir berikut.

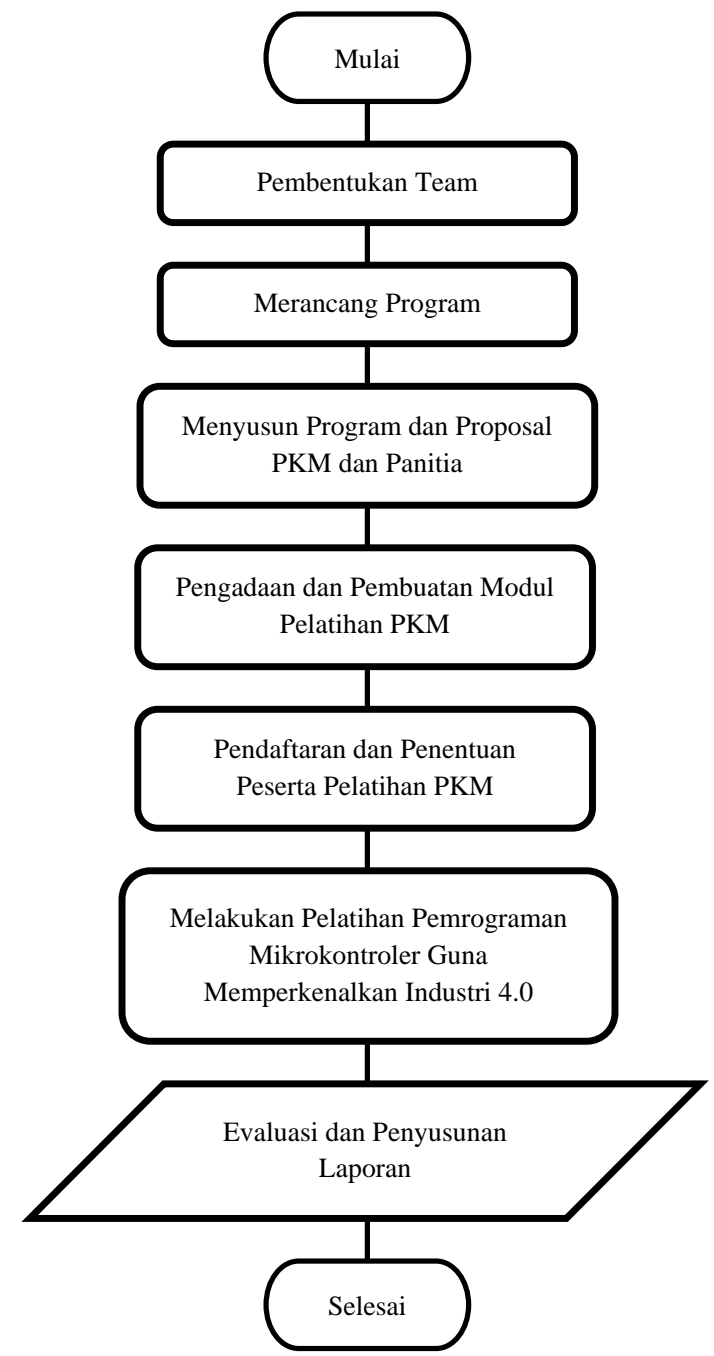

Gambar 1. Diagram Alir Kegiatan PKM 
Alat bantu berupa mikrokontroler, sensor dan driver motor dibuat oleh tim.Hand Out pelatihan juga dibuat untuk memudahkan para peserta memprogram mikrokontroler langkah demi langkah.Komputer yang dipakai untuk memprogram merupakan fasilitas dari sekolah di Laboratorium Komputer, Pelatihan dilakukan dalam tiga sesi. Target pelatihan ditujukan pada siswa yang berada di bangku kelas XI SMA. Di awal pelatihan siswa diberikan materi mengenai pengenalan Industri 4.0 dan hubungannya dengan pemrograman mikrokontroler. Setelah itu para siswa diberikan materi dasar untuk melakukan pemrograman pada mikrokontoler, secara khusus mikrokontroler yang dipakai adalah Arduino Uno [3]. Kemudian siswa diberi kesempatan memprogram mikrokontoler untuk:

1. Membuat lampu Blinking LED dan flip-flop dengan menggunakan lampu LED.

2. Menghidup matikan LED dengan sensor Photodioda.

3. Menggunakan sensor Photodioda untuk menghidup matikan putaran roda.

Pengukuran keberhasilan penelitian dilakukan dengan melakukan survey kepada para peserta setelah kegiatan. Survey berupa 5 skala Likert yang meminta pendapat peserta mengenai beberapa pernyataan berikut.

1. Saya senang belajar pelajaran mengenai Komputer

2. Pelatihan Mikrokontroler Arduino ini mudah diikuti

3. Saya tertarik mendalami Mikrokontroler Arduino

4. Ketika belajar mengenai komputer saya tertarik

5. Mikrokontroler menarik untuk dipelajari lebih dalam

6. Pelatihan Mikrokontroler Arduino ini sulit diikuti

7. Pelatihan ini menambah wawasan saya menenai Industri 4.0

8. Saya ingin ada pelajaran tambahan mengenai Mikrokontroler di sekolah saya

9. Saya mendapat pemahaman baru mengenai Industri 4.0

10. Jika ada pelajaran tambahan Mikrokontroler di sekolah, saya ingin ikut

Kuesioner yang diberikan kepada para peserta dinilai dengan skala Likert[4] yaitu "Tidak Setuju", "Kurang Setuju", "Netral", "Setuju" dan "Sangat Setuju". Kelebihan dari skala Likert yaitu kemudahan dalam menggunakannya, baik oleh peserta maupun oleh pembuat. Skala Likert juga fleksibel sehingga bisa dipakai dalam berbagai survey. Tetapi skala Likert juga punya kelemahan, yaitu karena asumsi item yang dipilih tidak memiliki nilai yang sama atau bisa dinyatakan dalam nilai. Seperti yang dikatakan oleh Jamieson bahwa rata-rata dari "Cukup" dan "Baik" bukanlah "Setengah Baik", demikian juga jika sebuah angka diberikan pada "Cukup" dan "Baik"[5].

Oleh sebab itu untuk mengambil kesimpulan dari Skala Likert biasa diambil data yang memiliki frekuensi terbanyak (Modus) berada di item mana dan berapa persen dari jumlah pemilih yang memilih item tersebut. Untuk membantu maka diambil Data terbanyak pertama dan kedua.

\section{HASIL DAN PEMBAHASAN}

\subsection{HASIL}

Bagi kelompok sasaran, yaitu siswa SMA Negeri 7 Tangerang Selatan. Peserta mendapat wawasan dan pemahaman baru mengenai Industri 4.0. Pelatihan ini juga sangat menumbuhkan minat para peserta untuk mendalami mengenai mikrokontroler. Kuesioner diisi oleh 39 orang peserta. Peserta yang mengikuti pelatihan memang dikhususkan bagi siswa yang tertarik belajar komputer, sehingga dari survey "Saya senang belajar pelajaran mengenai komputer" yang "Sangat Setuju" 79,48\% dan "Setuju" 17.94\%. Hasil kuesioner dijabarkan dalam Tabel 1. Modus yang diambil adalah Modus pertama dan kedua. 
Tabel 1. Hasil Kuesioner Peserta Pelatihan Mikrokontroler

\begin{tabular}{|c|c|c|c|c|c|c|c|c|c|}
\hline \multirow[t]{2}{*}{ No. } & \multirow[t]{2}{*}{ Pernyataan } & \multicolumn{5}{|c|}{$\begin{array}{c}\text { Jumlah Jawaban } \\
\text { Peserta }\end{array}$} & \multirow{2}{*}{$\begin{array}{c}\text { Modus } \\
\text { I/II }\end{array}$} & \multirow{2}{*}{$\begin{array}{l}\text { Persentase } \\
\text { Modus } \\
\text { I/II }\end{array}$} & \multirow{2}{*}{$\begin{array}{c}\text { Keterangan } \\
\text { I/II }\end{array}$} \\
\hline & & 1 & 2 & 3 & 4 & 5 & & & \\
\hline 1. & $\begin{array}{l}\text { Saya senang belajar } \\
\text { pelajaran mengenai } \\
\text { Komputer }\end{array}$ & 0 & 0 & 1 & 7 & 31 & $5 / 4$ & $79,48 / 17,94$ & $\begin{array}{l}\text { Sangat } \\
\text { Setuju/ } \\
\text { Setuju }\end{array}$ \\
\hline 2. & $\begin{array}{l}\text { Pelatihan Mikrokontroler } \\
\text { Arduino ini mudah } \\
\text { diikuti }\end{array}$ & 0 & 0 & 10 & 12 & 17 & $5 / 4$ & $43,58 / 30.76$ & $\begin{array}{l}\text { Sangat } \\
\text { Setuju/ } \\
\text { Setuju }\end{array}$ \\
\hline 3. & $\begin{array}{l}\text { Saya tertarik mendalami } \\
\text { Mikrokontroler Arduino }\end{array}$ & 0 & 1 & 8 & 13 & 17 & $5 / 4$ & $43,58 / 33,33$ & $\begin{array}{l}\text { Sangat } \\
\text { Setuju/ } \\
\text { Setuju }\end{array}$ \\
\hline 4. & $\begin{array}{l}\text { Ketika belajar mengenai } \\
\text { komputer saya tertarik }\end{array}$ & 0 & 0 & 4 & 18 & 17 & $4 / 5$ & $43,58 / 46,15$ & $\begin{array}{l}\text { Setuju/ } \\
\text { Sangat } \\
\text { Setuju }\end{array}$ \\
\hline 5. & $\begin{array}{l}\text { Mikrokontroler menarik } \\
\text { untuk dipelajari lebih } \\
\text { dalam }\end{array}$ & 0 & 0 & 9 & 17 & 13 & $4 / 5$ & $43,58 / 33,33$ & $\begin{array}{l}\text { Setuju/ } \\
\text { Sangat } \\
\text { Setuju } \\
\end{array}$ \\
\hline 6. & $\begin{array}{l}\text { Pelatihan Mikrokontroler } \\
\text { Arduino ini sulit diikuti }\end{array}$ & 8 & 16 & 11 & 3 & 1 & $2 / 3$ & $41,02 / 28,20$ & $\begin{array}{l}\text { Tidak } \\
\text { Setuju/ } \\
\text { Netral }\end{array}$ \\
\hline 7. & $\begin{array}{l}\text { Pelatihan ini menambah } \\
\text { wawasan saya menenai } \\
\text { Industri } 4.0\end{array}$ & 0 & 0 & 2 & 24 & 13 & $4 / 5$ & $61,53 / 33,33$ & $\begin{array}{l}\text { Setuju/ } \\
\text { Sangat } \\
\text { Setuju }\end{array}$ \\
\hline 8. & $\begin{array}{l}\text { Saya ingin ada pelajaran } \\
\text { tambahan mengenai } \\
\text { Mikrokontroler di } \\
\text { sekolah saya }\end{array}$ & 1 & 2 & 3 & 16 & 17 & $5 / 4$ & $43,58 / 41,02$ & $\begin{array}{l}\text { Sangat } \\
\text { Setuju/ } \\
\text { Setuju }\end{array}$ \\
\hline 9. & $\begin{array}{l}\text { Saya mendapat } \\
\text { pemahaman baru } \\
\text { mengenai } \\
\text { Industri } 4.0\end{array}$ & 0 & 1 & 5 & 17 & 16 & $4 / 5$ & $43,58 / 41,02$ & $\begin{array}{l}\text { Setuju/ } \\
\text { Sangat } \\
\text { Setuju }\end{array}$ \\
\hline 10. & $\begin{array}{l}\text { Jika ada pelajaran } \\
\text { tambahan Mikrokontroler } \\
\text { di sekolah, saya ingin } \\
\text { ikut }\end{array}$ & 1 & 0 & 7 & 14 & 17 & $5 / 4$ & $43,58 / 35.89$ & $\begin{array}{l}\text { Sangat } \\
\text { Setuju/ } \\
\text { Setuju }\end{array}$ \\
\hline
\end{tabular}

Keterangan: 1. Sangat Tidak Setuju, 2. Tidak Setuju. 3. Netral. 4. Setuju. 5. Sangat Setuju 

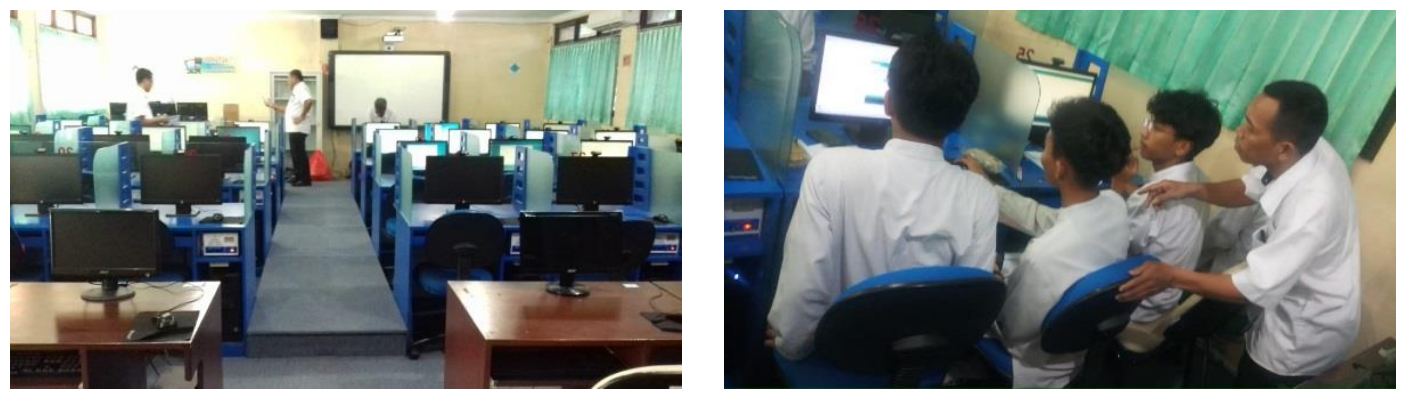

Gambar 2. Laboratorium Komputer SMA Negeri 7 Tangerang Selatan
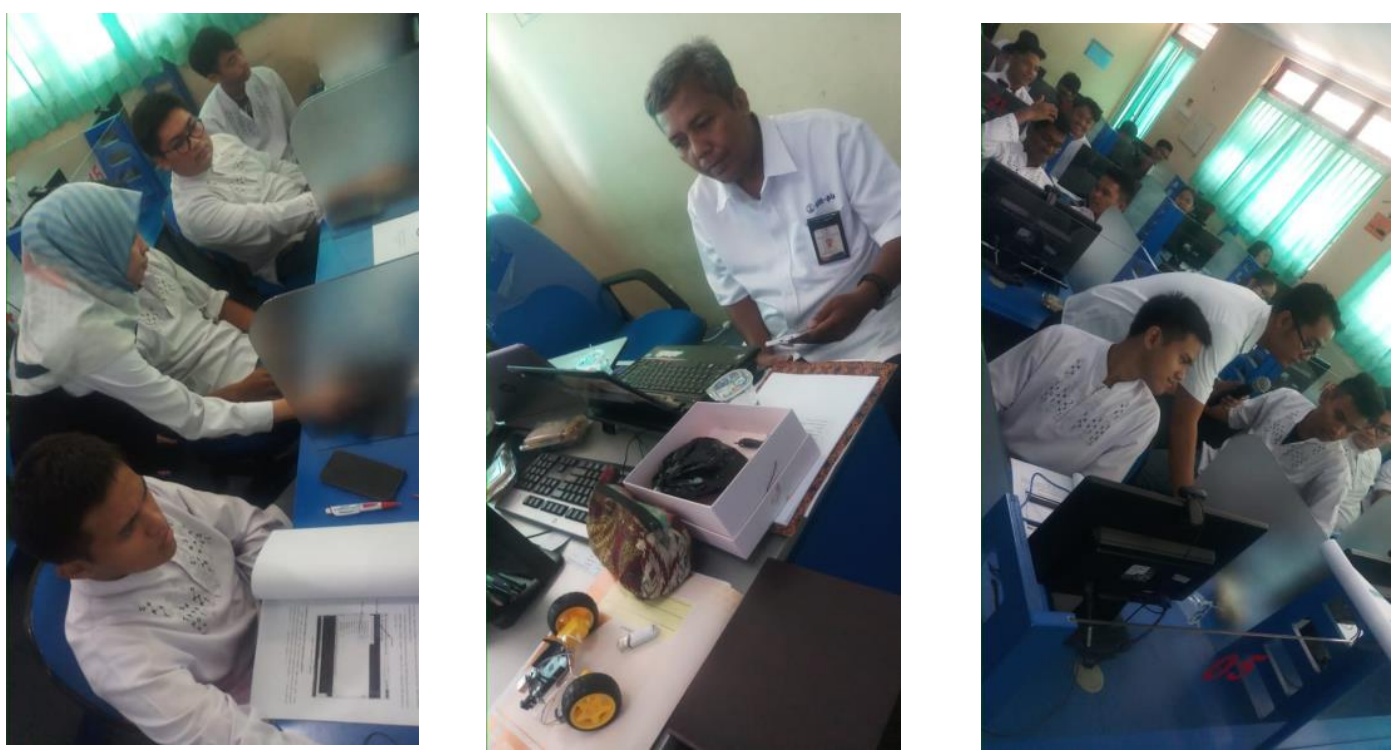

Gambar 3. Pendampingan memprogram Mikrokontroler

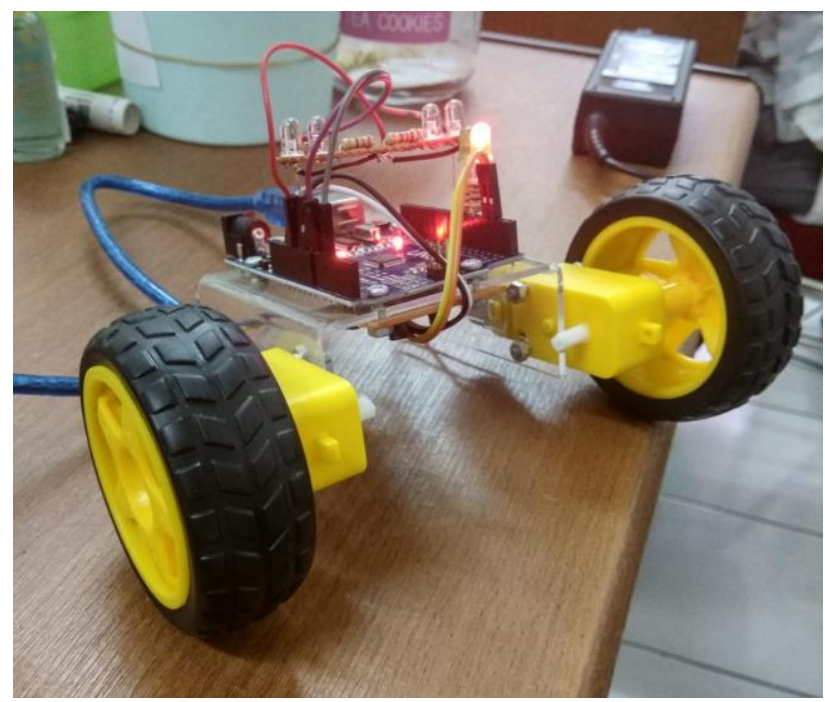

Gambar 4. Modul Pelatihan Mikrokontroler 
Alat pelatihan mikrokontroler sebanyak 20 unit dan telah dihibahkan 5 unit ke SMA Negeri 7 Tangerang Selatan agar ada bahan pembelajaran untuk siswa-siswi yang ingin mendalami mikrokontroler.

\subsection{PEMBAHASAN}

Dari hasil kuesioner didapatkan beberapa pernyataan penting yang perlu dievaluasi. Peserta "Setuju" sebanyak 61.53\% dan "Sangat Setuju" sebanyak 33,33\% bahwa pelatihan ini menambah wawasan mereka mengenai Industri 4.0 Peserta "Sangat Setuju" sebanyak 43,58\% dan "Setuju" sebanyak 33,33\% bahwa dirinya tertarik untuk mendalami Mikrokontroler Arduino. Peserta "Sangat Setuju" sebanyak 43,58\% dan "Setuju" sebanyak 41,02\% bahwa ingin ada pelajaran tambahan mengenai mikrokontroler di sekolah mereka.

Hal ini menujukkan bahwa sebenarnya banyak potensi yang dimiliki oleh para peserta di bidang pemrograman, sebab hampir seluruh peserta dapat mengikuti pelatihan dengan baik. Lebih daripada itu mereka juga ingin mendalami mengenai mikrokontroler. Ini sangat baik untuk menumbuhkan minat dan bakat para peserta di bidang teknik khususnya pemrograman, sebab di era Industri 4.0 pengetahuan mengenai pemanfaatan komputer adalah sangat dibutuhkan. Peserta juga menjadi tahu posisi mereka dan era yang akan mereka hadapi ketika bekerja nanti.

\section{KESIMPULAN}

Pelatihan Pemrograman Mikrokontroler Guna Mempekenalkan Industri 4.0 di SMA Negeri 7 Tangerang Selatan memberikan dampak positif bagi peserta maupun Tim PKM dan Institusi. Peserta "Setuju" sebanyak 61.53\% dan "Sangat Setuju" sebanyak 33,33\% bahwa pelatihan ini menambah wawasan mereka mengenai Industri 4.0. Peserta "Sangat Setuju" sebanyak 43,58\% dan "Setuju" sebanyak 33,33\% bahwa dirinya tertarik untuk mendalami Mikrokontroler Arduino. Peserta "Sangat Setuju" sebanyak 43,58\% dan "Setuju" sebanyak 41,02\% bahwa ingin ada pelajaran tambahan mengenai mikrokontroler di sekolah mereka.

Perkembangan Industri 4.0 mencakup berbagai bidang, sehingga akan membuka banyak sekali lapangan pekerjaan baru. Sehingga adalah sangat penting untuk mengetahui dampak dari era Industri 4.0 dan bagaimana menyikapi atau mempersiapkan diri maupun generasi selanjutnya untuk menghadapi era Industri 4.0.

\section{SARAN}

Penunjang Industri 4.0 meliputi banyak hal, antara lain mesin, perangkat, sensor dan manusia dalam pemanfaatan Internet of Things (IoT) guna menunjang komunikasi satu dengan lainnya. Enam hal dari desain Industry 4.0 adalah kemandirian, fleksibilitas operasi, transparansi informasi, dukungan teknis, akuisisi dan pemrosesan data secara real-time, modularitas dan keputusan terdistribusi [6]. Oleh karena itu Industri 4.0 masih akan sangat berkembang pesat ke depan sehingga tidak rugi untuk dipelajari secara mendalam.

Pemerintah Indonesia juga sedang menggalangkan Education 4.0 yang mengarah kepada pemanfaatan teknologi guna menunjang pendidikan yang ada saat ini. Generasi milenial yang saat ini berada pada jenjang pendidikan SMP dan SMA sangat banyak menghabiskan waktu dengan gadget [7]. Mereka menjadi sulit untuk belajar menggunakan buku dan lebih tertarik dengan melihat hal-hal baru, menonton video dan berinteraksi lewat media sosial. Hal ini bisa menjadi dampak negatif buat generasi milenial, tetapi juga bisa menjadi efek positif. Efek negatifnya adalah semakin lama menggunakan gadget maka akan semakin memunculkan sifat ketergantungan pada gadget. Efek 
positifnya adalah kemudahan dalam mendapatkan informasi termasuk ilmu pengetahuan menjadi sangatlah mudah.

Tahapan selanjutnya yang mungkin bisa dilakukan oleh Tim PKM adalah mengadakan pelatihan online mikrokontroler untuk para siswa yang tertarik belajar mikrokontroler. Saat ini sudah sangat banyak media pembelajaran yang dapat dimanfaatkan untuk membuat pelatihan atau pengajaran. Menimbang bahwa genarasi milenial saat ini sangat suka menggunakan gadget mereka, maka beberapa media pembelajaran yang bisa diapakai adalah Youtube dan Aplikasi Ruang Guru.

\section{UCAPAN TERIMA KASIH}

Penulis beserta seluruh tim dosen dan mahasiswa PKM Teknik Elektro STT-PLN mengucapkan banyak terima kasih kepada pihak LPPM STT-PLN Jakarta atas dukungannya yang akan memberikan dana P2M dan segala macam arahan dan bantuan yang diberikan kepada tim kami sehingga kami dapat menyelesaikan laporan kegiatan PKM ini dengan baik dan lancar.

Terima kasih juga penulis beserta seluruh tim dosen dan mahasiswa PKM ucapkan untuk guru-guru dan peserta dari SMA Negeri 7 Tangerang Selatan dalam menyukseskan kegiatan pelatihan ini.

\section{DAFTAR PUSTAKA}

[1] A. Kurniawan, “'Coding' Siap Masuk ke Dalam Kurikulum Sekolah di Indonesia"," 2018. [Online]. Available: https://edukasi.kompas.com/read/2018/01/12/07015971/coding-siapmasuk-ke-dalam-kurikulum-sekolah-di-indonesia.

[2] H. Prasetyo and W. Sutopo, "INDUSTRI 4.0: TELAAH KLASIFIKASI ASPEK DAN ARAH PERKEMBANGAN RISET,” J@ti Undip J. Tek. Ind., vol. 13, no. 1, p. 17, Mar. 2018.

[3] Y. A. Badamasi, "The working principle of an Arduino," in 2014 11th International Conference on Electronics, Computer and Computation (ICECCO), 2014, pp. 1-4.

[4] A. Joshi, S. Kale, S. Chandel, and D. Pal, Likert Scale: Explored and Explained, vol. 7. 2015.

[5] S. Jamieson, "Likert scales: how to (ab)use them.," Med. Educ., vol. 38 12, pp. 1217-1218, 2004.

[6] M. Baygin, H. Yetis, M. Karakose, and E. Akin, "An effect analysis of industry 4.0 to higher education," in 2016 15th International Conference on Information Technology Based Higher Education and Training (ITHET), 2016, pp. 1-4.

[7] S. Gideon and U. K. Indonesia, "PERAN MEDIA BIMBINGAN BELAJAR ONLINE “ RUANGGURU ' DALAM PEMBELAJARAN IPA BAGI SISWA SMP DAN SMA MASA KINI : SEBUAH PENGANTAR," pp. 167-182. 